\title{
POTENSI DAN PERSEPSI MASYARAKAT SERTA WISATAWAN TERHADAP PENGEMBANGAN EKOWISATA DI DESA AIK BERIK, LOMBOK TENGAH
}

\author{
Murianto \\ Program Studi Magister Kajian Pariwisata \\ Universitas Udayana \\ Email: antoterakoh@yahoo.com
}

\begin{abstract}
Aik Berikvillage has a wide variety of tourist attractions. This research is aimed at identifying potential ecotourism attractions, activities that could be developed in and around the village. In addition, it will investigate perceptions of local communities and tourists concerning the village's potential development as an ecotourism destination. The supporting data in the research were collected through qualitative observation, in-depth interviews, questionnaires, and documentation. The data were obtained through purposive sampling for the local communities and convenience sampling for the tourists. It was analysed using a descriptive, qualitative method. This analysis has revealed both positive and negative perceptions among local communities and tourists in response to the potential development of ecotourism.
\end{abstract}

Keywords: potential, perceptions, ecotourism, Aik Berik village.

\section{Pendahuluan}

- kowisata merupakan jenis pariwisata yang mulai populer

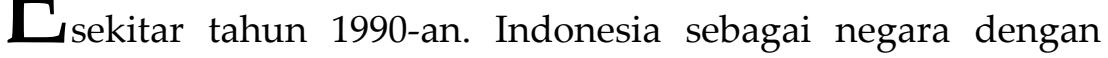
mega biodeversitas, Indonesia memiliki potensi yang cukup baik di dalam pengembangan jenis pariwisata ini (Dalem, 2002). Pulau Lombok dengan berbagai potensi alamnya antara lain Gunung Rinjani, potensial di dalam pengembangan ekowisata, apalagi letaknya berdekatan dengan Bali sebagai destinasi wisata utama di Indonesia. Artikel yang terkait dengan ekowisata ini belum pernah diteliti di Desa Aik Berik. 
Desa Aik Berik merupakan salah satu desa di Lombok Tengah yang memiliki potensi alam sebagai daya tarik pariwisata. Kondisi alam dan sumber mata air di Desa Aik Berik yang dapat dijadikan daya tarik wisata yaitu Air Terjun Benang Setokel, Air Terjun Benang Kelambu dan Air Terjun Kelewon. Pemerintah Lombok Tengah menjadikan Desa Aik Berik sebagai wilayah sumber air bersih yang digunakan oleh Perusahaan Daerah Air Minum (PDAM) Lombok Tengah untuk masyarakat Kota Praya (Hadi, 2010). Pengembangan Desa Aik Berik sebagai salah satu destinasi wisata menunjukan perkembangan yang positif. Adapun perkembangan positif bisa dilihat dari perkembangan kunjungan wisatawan di Desa Aik Berik. Secara umum terjadi fluktuasi jumlah kunjungan wisatawan selama kurun waktu lima tahun terkhir akan tetapi minat wisatawan untuk mengunjungi daya tarik wisata menunjukan trend yang positif. Pada tahun 2009, kunjungan wisatawan mengalami penurunan sebesar 9,01 $\%$ dan tahun 2010 mengalami penurunan sebesar 0,70 \%. Namun demikian, pada tahun 2011 mengalami peningkatan sebesar 14,90 dan pada tahun 2012 meningkat sebesar 2,47 \% (Humaidi, 2013).

Desa Aik Berik memiliki kondisi alam yang alami, memiliki banyak jenis tumbuh-tumbuhan serta hasil buah-buahan yang beranekaragam. Ada beberapa macam buah-buahan di Desa Aik Berik seperti Pisang, Kopi Lombok, Cokelat, Mangga, Pepaya, Kelapa, Durian, Panili, Nangka, Manggis yang dihasilkan dari kebun. Masyarakat Desa Aik Berik sebagian besar berkerja sebagai petani dan pekebun dengan tingkat pendidikan rata-rata SD dan SLTP. Pengetahuan pariwisata dan pentingnya menjaga lingkungan masih sangat kurang, hal ini terlihat dari keterlibatan masyarakat dalam pengelolan dan pengembangan destinasi wisata. Masyarakat Desa Aik Berik melakukan penebangan pohon untuk dijual sebagai kayu bakar tanpa mempertimbangkan kelestarian lingkungan, hal ini disebabkan karena hasil mata pencaharian yang diperoleh masih belum mencukupi kebutuhan hidupnya (Hadi, 2010). 
Pengembangan Desa Aik Berik sebagai destinasi wisata tergolong belum memadai. Beberapa sarana dan prasana fasilitas pariwisata tidak dijaga dengan baik seperti beberapa bak sampah yang sudah rusak, toilet rusak, bale-bale kecil (bale bengong) sudah rusak, jalan setapak yang terjal dan tidak terawat, tempat parkir yang becek, pedagang kaki lima yang tidak teratur, kurangnya penunjuk jalan dan fasilitas pendukung lainya (Hadi, 2010). Pengembangan potensi wisata akan dipengaruhi oleh jumlah fasilitas pendukung pariwisata yang disediakan. Masyarakat dan wisatawan menyadari bahwa ada beberapa aktivitas wisata yang sedang dikembangkan di Desa Aik Berik seperti trekking Gunung Rinjani. Pengembangan aktivitas wisata ini belum dikelola dengan baik sehingga masyarakat tidak merasakan hasil yang maksimal (Humaidi, 2013).

Pengembangan pariwisata di Desa Aik Berik membuka lapangan kerja bagi masyarakat lokal. Beberapa aktivitas yang bisa melibatkan masyarakat seperti Guide lokal, pedagang kaki lima, petugas keamanan dan parkir. Berdasarkan kondisi tersebut, maka jenis pariwisata yang dapat dikembangkan adalah ekowisata. Konsep ekowisata merupakan salah satu konsep yang sudah dikembangkan sejak tahun 1980-an. Konsep ekowisata yang terdiri dari pelestarian lingkungan, peningkatan partisipasi masyarakat, meningkatkan pertumbuhan ekonomi lokal, sudah dikembangkan di beberapa destinasi wisata di Indonesia, karena perkembanganya selalu konsisten dengan dua prinsip dasar yaitu memberikan keuntungan ekonomi langsung kepada masyarakat lokal dan turut memberikan andil dalam pelestarian lingkungan (Sudarto, 1990). Pengembangan ekowisata memiliki kepedulian terhadap pelestarian lingkungan, melibatkan masyarakat lokal dan menjaga kelestarian budaya masyarakat. Pengembangan ekowisata yang melibatkan masyarakat sangat penting untuk membuka lapangan kerja, memberikan pemahaman tentang pariwisata, dan meningkat kondisi ekonomi masyarakat. Berdasarkan pemaparan latar belakang di atas, maka artikel ini membahas dua hal yaitu (1) Apakah potensi-potensi ekowisata di Desa Aik Berik? 
(2) Bagaimanakah persepsi masyarakat dan wisatawan terhadap pengembangan ekowisata di Desa Aik Berik?

\section{Teori dan Metode}

\subsection{Teori Persepsi}

Pariwisata ada karena adanya wisatawan dan wisatawan pada intinya adalah orang sedang tidak bekerja, atau sedang berlibur, dan secara sukarela mengunjungi daerah lain untuk mendapatkan sesuatu yang berbeda dari tempat asal (Pitana, 2005).

Persepsi menurut (Irianto, 2011) bila seorang individu memandang pada satu obyek dan mencoba menafsirkan apa yang dilihatnya, penafsiran itu sangat dipengaruhi oleh karakteristik dari pribadi dan perilaku persepsi individu itu. Karakteristik pribadi yang lebih relevan yang mempengaruhi persepsi adalah sikap, motif, kepentingan atau minat, pengalaman masa lalu, dan pengharapan (expectation). Demikian juga, (Jumail, 2012) menjelaskan persepsi sangat dipengaruhi oleh gerakan, bunyi, ukuran, dan atribut-atribut lain sehingga membentuk cara kita memandangnya. Ketika menilai sesuatu tidak dipandang dalam keadaan tersolasi, hubungan suatu target dengan latar belakangnya mempengaruhi persepsi, seperti kecenderungan kita untuk mengelompokkan benda-benda yang berdekatan atau mirip. Unsur-unsur lingkungan sekitar daya tarik wisata mempengaruhi persepsi. Waktu adalah dimana suatu obyek atau peristiwa itu dilihat agar dapat mempengaruhi perhatian, seperti juga lokasi, cahaya, panas, atau setiap jumlah faktor situasional.

Persepsi sebagai proses yang digunakan seorang individu untuk memilih, mengorganisasikan, dan menginterprstasi masukan-masukan informasi guna menciptakan gambaran dunia yang memiliki arti, persepsi tidak hanya tergantung pada rangsangan fisik, tetapi juga pada rangsangan yang berhubungan dengan lingkungan sekitar dan keadaan individu yang bersangkutan (Ramadhan, 2009).

Berdasarkan uraian persepsi tersebut dapat diambil kesimpulan bahwa persepsi merupakan cara pandang, tindakan, 
dan gambaran yang diberikan seseorang terahadap sesuatu yang berada di sekitar lingkungannya baik persepsi yang diberikan positif atau negatif. Pada artikel ini Teori persepsi digunakan dalam menentukan persepsi masyarakat dan wisatawan terhadap pengembangan ekowisata di Desa Aik Berik.

\subsection{Metode}

Artikel ini menggunakan metode analisis deskriftif kualitatif dengan metode pengumpulan data ada empat yaitu observasi, wawancara mendalam, penyebaran angket, dan dokumentasi yang diuraikan sebagai berikut :

\subsubsection{Observasi}

Observasi dilakukan dengan cara melakukan pengamatan secara langsung untuk mendapatkan gambaran yang jelas mengenai kondisi atau keadaan Desa Aik Berik. Observasi dilakukan dengan pengamatan potensi alam dan budaya, sarana \& prasarana wisata serta pengelolaan pariwisata seperti potensi ekowisata perkebunan, persawahan, air terjun, kondisi masyarakat, kondisi hutan, dan fasilitas-fasilitas umum di daya tarik ekowisata Desa Aik Berik. Observasi ini diarahkan pada kegiatan wisata di Desa Aik Berik dengan cara mengamati dan mengikuti aktivitas ekowisata yang dibantu dengan menggunakan instrumen kamera dan tape recorder (Kriyanto, 2010).

\subsubsection{Wawancara mendalam (In-depth Interview)}

Pengumpulan data dengan wawancara yaitu melakukan tanya jawab secara langsung kepada masyarakat untuk mengetahui data yang berhubungan dengan gejala sosial, budaya maupun ekonomi yang sifatnya kompleks. Metode penentuan informan menggunakan purposif sampling yaitu pihak yang dianggap berkompeten memberikan gambaran dan informasi yang digunakan untuk menjawab permasalahan yang ada dalam penelitian ini. Data yang tidak bisa diperoleh dengan data observasi diatasi melalui wawancara mendalam dengan informan 
informan seperti Kepala Desa Aik Berik, tokoh masyarakat, tokoh keamanan, tokoh agama, masyarakat dan pengelola pariwisata.

\subsubsection{Penyebaran Angket (Kuisioner)}

Penyebaran angket/kuisioner dilakukan untuk mengetahui persepsi wisatawan dan masyarakat. Metode ini dilakukan untuk mengetahui persepsi masyarakat dan wisatawan terhadap potensi-potensi serta pengembangan Desa Aik Berik yang akan dikembangkan sebagai ekowisata yang berkelanjutan. Teknik penentuan responden menggunakan sampel kebetulan (accidental sampling) yaitu memilih siapa saja wisatawan atau masyarakat yang dijumpai untuk dijadikan sampel. Dari hasil penyebaran angket kepada 62 orang wisatawan dan 30 orang masyarakat kemudian hasil angaket ditabulasikan sehingga akan memperoleh persepi masyarakat dan wisatawan terhadap pengembangan ekowisata di Desa Aik Berik.

\subsubsection{Dokumetasi}

Seluruh hasil pengumpulan data akan didokumentasikan baik dalam bentuk hard file maupun soft file untuk memperoleh tabulasi, interpretasi, dan analisis data lebih lanjut. Dokumentasi seperti gambar lingkungan Desa Aik Berik, gambar kondisi alam Desa Aik Berik, kondisi perkampungan, data yang terkait dengan pembangunan sarana dan prasarana daya tarik ekowisata.

\section{Potensi Ekowisata di Desa Aik Berik}

Potensi ekowisata di Desa Aik Berik terdiri dari empat potensi yaitu penorama persawahan, panorama perkebunan, sungai, dan air terjun yang akan dibahas sebagai berikut.

\subsection{Potensi Panorama Persawahan}

Masyarakat Desa Aik Berik memiliki suasana persawahan yang sangat alami. Kondisi tersebut memberikan pemandangan yang hijau, alami dan menenangkan hati setiap orang yang memandangnya. Luasnya pemandangan persawahan 


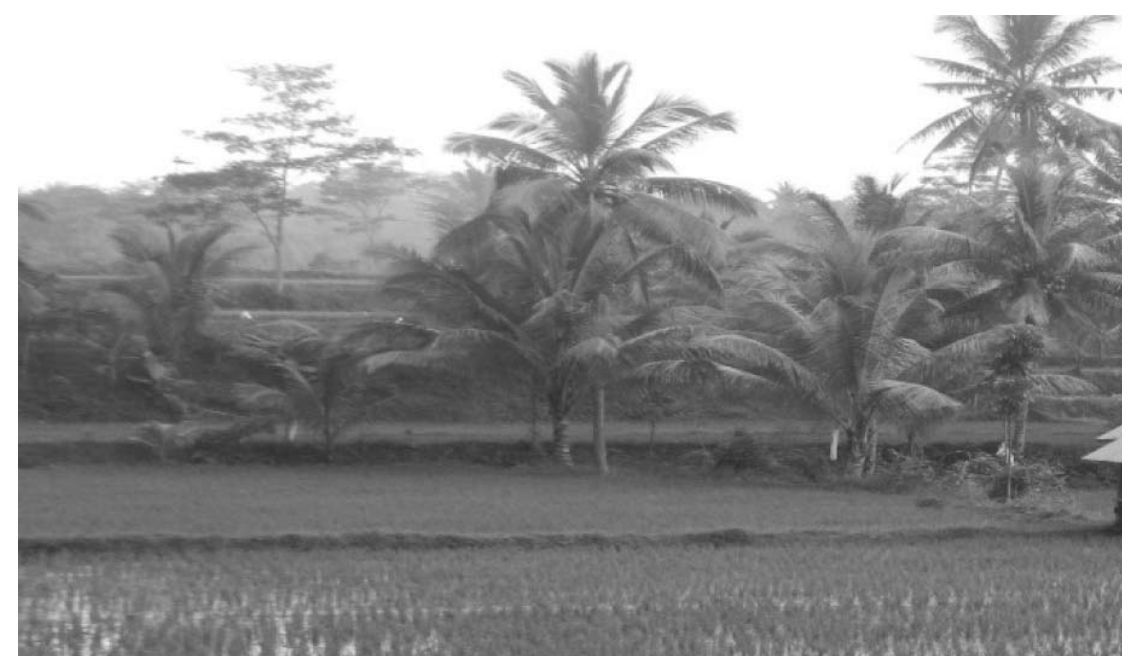

Persawahan Desa Aik Berik, persawahan merupakan salah satu daya tarik ekowisata. Kegiatan ekowisata yang bisa dilakukan, seperti Soft trekking, tradisional farming, dan cycling. (Foto oleh Murianto)

memberikan daya tarik yang khusus apabila dibandingkan dengan desa lainya di Kecamatan Batu Keliang Utara. Kondisi persawahan yang ditunjang dengan sumber daya air yang cukup akan mempengaruhi kondisi pertanian. Masyarakat menanam padi sebagai sumber bahan makanan pokok sehari hari.

\subsection{Potensi Panorama Perkebunan}

Desa Aik Berik memiliki kebun yang asri dan indah. Berbagai jenis tanaman yang ditanam di Desa Aik Berik seperti jeruk, kopi, mangga, durian, manggis dan nangka. Keberadaan kebun memberikan pengaruh terhadap jumlah air yang bisa digunakan oleh masyarakat secara umum. Jenis buah-buahan yang dihasilkan dan sudah dipasarkan oleh petani kebun di Desa Aik Berik adalah kelapa, jambu mente, mangga, kopi, nanas, durian, jeruk, apokat, dan manggis.

\subsection{Potensi Sungai}

Sungai merupakan salah satu potensi ekowisata yang dimiliki Desa Aik Berik. Sungai-sungai yang ada di Desa Aik Berik memiliki air yang jernih dan debit air yang besar. Sumber air 


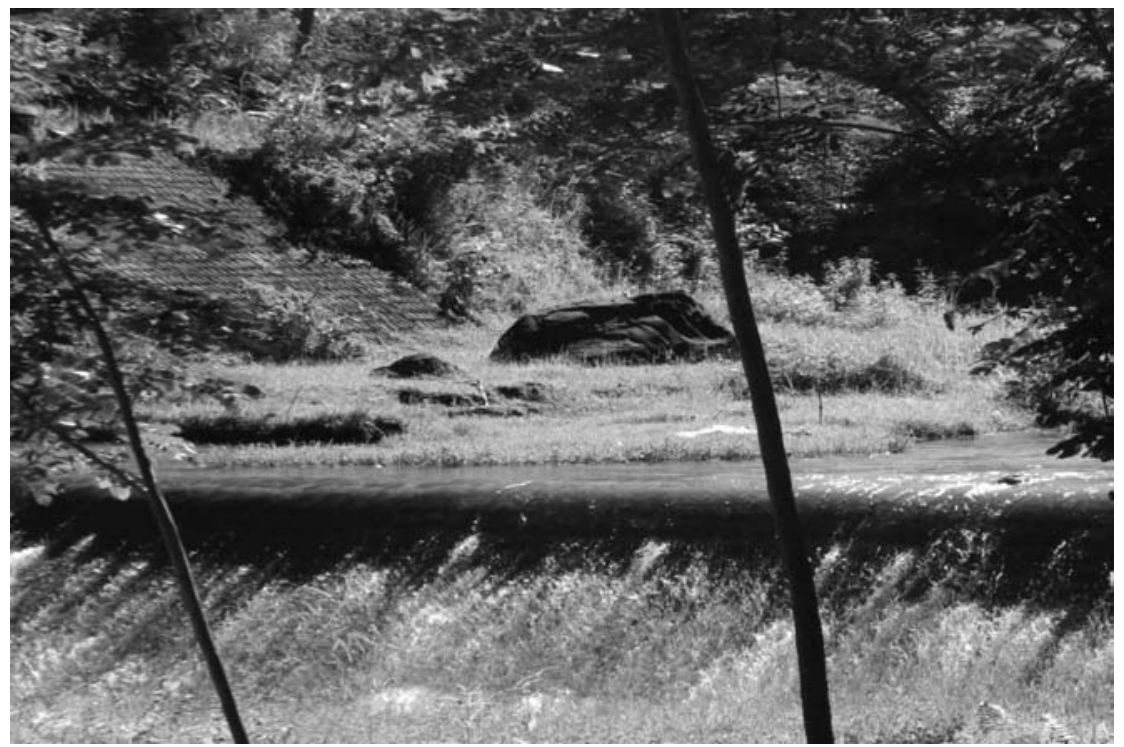

Sungai di Desa Aik Berik, Sungai merupakan salah satu daya tarik ekowisata. Kegiatan ekowisata yang bisa dilakukan seperti Soft trekking, rafting, river tubing, dan river boarding. (Foto oleh Murianto)

sungai datang dari sumber mata air yang banyak bermunculan termasuk beberapa Air Terjun seperti Air Terjun Benang Stokel, Benang Kelambu dan Air Terjun Kelewon. Sungai di Desa Aik Berik memiliki pemandangan pepohonan, air terjun kecil, tebing dan beberapa sawah serta perkebunan di pinggir sungai. Kondisi sungai seperti ini bisa dikembangkan beberapa olah raga air di Desa Aik Berik. disamping itu juga, air yang tidak terpakai dari sumber mata air yang ada di Desa Aik Berik dialirkan ke sungaisungai sebagai saluran irigasi bagi para petani. Pada musim hujan sungai memiliki debit air yang sangat besar dan dapat menghindari masyarakat dari banjir.

\subsection{Potensi Air Terjun di Desa Aik Berik}

Desa Aik Berik memiliki panorama alam yang indah. Air Terjun merupakan salah satu daya tarik bagi wisatawan yang mengunjugi desa. Ada beberapa air terjun yang ada di Desa Aik Berik yaitu Air Terjun Benang Stokel, Air Terjun Benang Kelambu dan Air Terjun Kelewon. Ketiga air terjun ini merupakan daya 


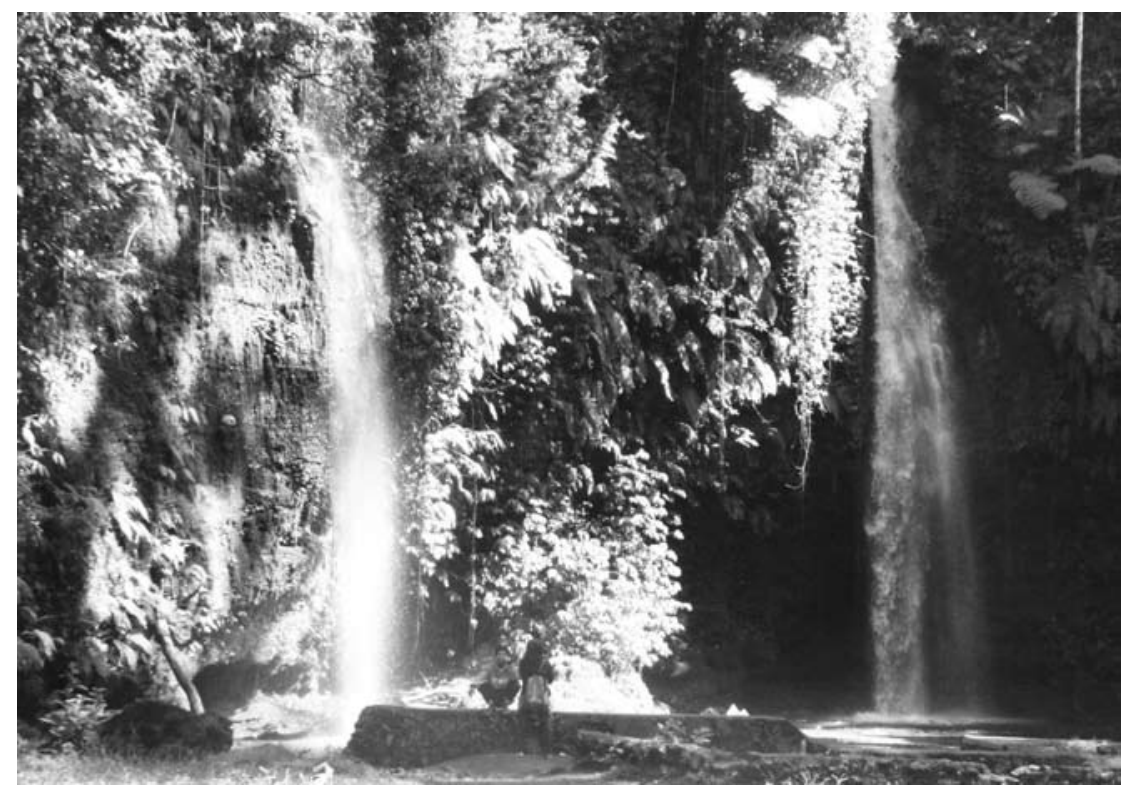

Air Terjun Benang Stokel di Desa Aik Berik, Air terjun merupakan salah satu daya tarik ekowisata. Kegiatan ekowisata yang bisa dilakukan seperti trekking, canyoning, dan kegiatan camping di sekitar air terjun. (Foto Murianto)

tarik yang sangat diminati oleh wisatawan. Air terjun ini berada di sekitar hutan lindung di Desa Aik Berik. Kondisi hutan lindung dijaga oleh pemerintah dan masyarakat. Banyak wisatawan domestik dan mancanegara mengunjungi air terjun di Desa Aik Berik dengan melakukan soft trekking

\section{Persepsi masyarakat untuk pembangunan ekowisata}

Adapun persepsi masyarakat dalam artikel ini yang terkait dengan cara pandang dan pendapat sesuai dengan kondisi di daya tarik wisata terbagi menjadi dua yaitu persepsi positif dan persepsi negatif yang diuraikan sebagai berikut.

\subsection{Persepsi Positif}

Persepsi positif masyarakat di Desa Aik Berik terkait dengan beberapa hal yaitu pengembangan ekowisata, jalur trekking menuju Gunung Rinjani, pelestarian ekosistem tumbuhtumbuhan, keterlibatan masyarakat dalam pengembangan 
ekowisata, pemberian pelatihan pariwisata kepada masyarakat, pembangunan Hotel $\mathcal{E}$ Restourant dan pengembangan agrowisata, serta pengembangan air terjun sebagai daya daya tarik ekowisata yang diuraikan sebagai berikut :

Persepsi masyarakat terhadap pengembangan ekowisata di Desa Aik Berik. Masyarakat Desa Aik Berik pada dasarnya mendukung pengembangan ekowisata secara berkelanjutan baik dalam jangka pendek dan jangka panjang. Dukungan tersebut dapat ditunjukan dengan dukungan $60 \%$, masyarakat menyatakan sangat setuju terhadap pengembangan ekowisata, kemudian $33.33 \%$, masyarakat menyatakan setuju dan sebagian kecil masyarakat yang menyatakan netral sebesar $6.66 \%$ terhadap pengembangan ekowisata.

Persepsi Masyarakat terhadap pengembangan jalur trekking ke Gunung Rinjani di Desa Aik Berik. Pengembangan jalur trekking menuju Gunung Rinjani mendapat tanggapan yang positif dari masyarakat Desa Aik Berik. Pengembangan jalur trekking akan memberikan dampak jumlah kunjungan wisatawan di Desa Aik Berik karena jalur ini merupakan jalur trekking tercepat dibandingkan dengan jalur trekking di Senaru Lombok Utara dan Sembalun Lombok Timur. Masyarakat Desa Aik Berik sangat mendukung perkembangan trekking yang hal itu ditunjukan dengan pendapat masyarakat sebesar $53.33 \%$ menyatakan sangat setuju. kemudian, masyarakat menyatakan Setuju 46.66 \%. Maka dari hal tersebut dapat dilihat bahwa pengembangan trekking menuju Gunung Rinjani sangat dicita-citakan oleh masyarakat Desa Aik Berik.

Persepsi Masyarakat terhadap pelestarian ekosistem tumbuh-tumbuhan di Desa Aik Berik. Pelestarian ekosistem merupakan hal yang sangat penting dalam mengembangkan ekowisata. Tumbuh-tumbuhan akan memberikan pengaruh terhadap kondisi alam dan air di Desa Aik Berik. Masyarakat Desa Aik Berik memberikan peran penting dalam pelestariannya, oleh karena itu dukungan masyarakat sangat penting dalam pelestarian lingkungan. Dukungan masyarakat Desa Aik Berik dapat dilihat 
dari persepsinya bahwa masyarakat yang menyatakan sangat setuju terhadap pelestarian ekosistem tumbuh-tumbuhan sebesar $16.66 \%$, masyarakat menyatakan setuju $40 \%$, masyarakat yang menyatakan netral $13.33 \%$. Melihat hal tersebut maka, Pelestarian lingkungan khususnya tumbuh-tumbuhan sangat didukung oleh masyarakat dan dapat dilakukan secara bersama-sama sehingga akan memberikan dampak yang sangat signifikan terhadap perkembagan ekowisata yang bebasis pada alam.

Persepsi masyarakat terhadap keterlibatan masyarakat dalam pengembangan wisata di Desa Aik Berik. Masyarakat Desa Aik Berik memiliki padangan yang sederharna terhadap pengembangan ekowisata. Perubahan padangan masyarakat terhadap ekowisata dapat dilakukan dengan melibatkan masyarakat dalam aktivitas dan memberikan dampak ekonomi bagi kehidupanya. Melibatkan masyarakat secara langsung menjadi harapan masyarakat yang hal tersebut dapat dilihat dari persepsi masyarakat sebesar $43.33 \%$ yang menyatakan sangat setuju, masyarakat yang menyatakan netral sebesar 40\%, Dengan melihat aspirasi masyarakat maka pengembangan ekowisata Desa Aik Berik harus melibatkan masyarakat sehingga memberikan dampak yang positif bagi masyarakat kedepan.

Persepsi masyarakat terhadap pemberian pelatihan pariwisata di Desa Aik Berik. Ilmu pengetahuan dan keterampilan memiliki harga yang mahal bagi masyarakat. Kemampuan masyarakat untuk melanjutkan pendidikan masih sangat minim sehingga kualitas keterampilan dan pengalaman masih di bawah rata-rata standar pariwiasata. Pemberian pelatihan kepada masyarakat diharapkan walaupun masyarakat masih belum mengerti akan dampak bagi pelatihan tersebut. Persepsi masyarkat bisa dilihat bahwa masyarakat yang menyatakan setuju sebesar $13.33 \%$, masyarakat yang menyatakan netral sebesar $50 \%$, masyarakat menyatakan tidak setuju $23.33 \%$, Oleh karena itu, dari persepsi tersebut masyarakat Desa Aik Berik masih belum sepenuhnya mengetahui dampak dari pelatihan yang terkait dengan pelatihan pariwisata. 
Persepsi masyarakat terhadap pembangunan Hotel $\mathcal{E}$ Restourant diDesaAikBerik. Hotel dan Restaurant merupakan sarana pendukungdalampengembangandayatarikwisata.Pembangunan sarana ini akan memberikan dampak positif terhadap terbukanya lapangan kerja bagi masyarakat. Pembangunan Hotel dan Restaurant harus mendapatkan persetujuan masyarakat setempat. Masyarakat mendukung pembangunan Hotel \& Restaurant dapat dilihat dari persepsi masyarakat yang menyatakan setuju sebesar $46.66 \%$. Oleh karena itu, secara umum masyarakat di Desa Aik Berik mendukung terhadap pembangunan Hotel $\mathcal{E}$ Restourant yang dapat memberikan lapangan kerja bagi masyarakat dan peningkatan taraf ekonomi masyarakat. Terbukanya lapangan kerja akan mendorong kreatifitas masyarakat untuk belajar dan bekerja keras demi memperoleh kesejahteraan yang lebih baik.

Persepsi masyarakat terhadap pengembangan Agrowisata di Desa Aik Berik. Agrowisata memiliki hubungan yang sangat erat dengan pengembangan ekowisata. Kecamatan Batu Keliang Utara memiliki potensi yang besar terhadap pengembangan agrowisata karena didukung oleh kondisi geografis yang bagus untuk pengembangan agrowisata. Desa Aik Berik merupakan salah satu desa di Kecamatan Batu Keliang Utara yang memiliki potensi Agrowisata yang belum dikelola dengan baik. Masyarakat Desa Aik Berik mendukung jika ada pengembangan agrowisata dan akan memberikan dampak bagi perkembagan ekonomi masyarakat. Dukungan masyarakat tersebut bisa dilihat dari persepsi masyarakat yang menyatakan sangat setuju sebesar $6.6 \%$ dan setuju sebesar $43.33 \%$ terhadap pengembangan agrowisata.

Persepsi masyarakat terhadap pengembangan Air Terjun Benang Stokel, Benang Kelambu dan Air Terjun Kelewon sebagai daya tarik ekowisata. Desa Aik Berik memiliki 3 (tiga) air terjun yang merupakan daya tarik ekowisata. Pengembangan air terjun merupakan aset ekowisata yang tidak dimiliki oleh daerah lainya. Keberadaan air terjun ini juga dimamfaatkan masyarakat untuk digunakan sebagai sumber mata air. Selama ini masyarakat mendukung pengembangan ekowisata di Desa Aik Berik yang men- 
jadikan air terjun sebagai salah satu daya tarik wisata. Dukungan tersebut terlihat dengan persepsi masyarakat yang menyatakan sangat setuju sebesar $53.33 \%$, masyarakat menyatakan setuju sebesar $36.66 \%$. Jumlah masyarakat yang mendukung pengembangan air terjun sebagai daya tarik ekowisata sangat besar.

\subsection{Persepsi Negatif}

Adapun persepsi negatif yang diberikan oleh masyarakat yang terkait dengan beberapa hal yaitu akses jalan menuju daya tarik wisata, fasilitas umum, keterlibtan lembaga swadaya masyakat, dan kondisi keamanan yang diuraikan sebagai berikut:

Persepsi masyarakat terhadap perbaikan jalan menuju daya tarik wisata di Desa Aik Berik. Akses jalan merupakan faktor pendukung berkembangnya pariwisata. Beberapa ruas jalan di Desa Aik Berik membutuhkan perbaikan. Masyarakat berharap perbaikan jalan dapat dilakukan segera demi perbaikan ekonomi dan akses yang cepat menuju Desa Aik Berik. Perbaikan jalan sangat diharapkan yang ditunjukan dengan persepsi masyarakat yang menyatakan sangat setuju sebesar 53.33\%, masyarakat menyatakan setuju 30\%. Oleh karena itu, dapat disimpulkan bahwa sebagian besar masyarakat sangat menharapkan perbaikan jalan, baik jalan yang menghubungkan antardusun maupun antardesa.

Persepsi Masyarakat terhadap penambahan sarana fasilitas umum di lokasi daya tarik ekowisata Desa Aik Berik. Fasilitas-fasilitas umum merupakan salah satu penunjang yang sangat penting di daya tarik ekowisata di Desa Aik Berik. Fasilitas umum yang ada di daya tarik wisata sudah rusak dan tidak layak digunakan lagi oleh wisatawan dan masyarakat. Keberadaan fasilitas umum tersebut memberikan kesan negatatif sehingga perlu diadakan perbaikan. Pengembangan fasilitas tersebut sangat diharapkan oleh masyarakat di Desa Aik Berik. Hal tersebut ditunjukan bahwa masyarakat yang sangat setuju terhadap penambahan fasilitas umum sebesar $56.66 \%$, masyarakat menyatakan Setuju 40\%, masyarakat menyatakan netral $3.33 \%$. Maka dari hal tersebut dapat disimpulkan bahwa masyarakat 
Desa Aik Berik membutuhkan penambahan fasilitas sarana umum khususnya di daya tarik wisata.

Persepsi masyarakat terhadap keterlibatan Lembaga Swadaya Masyarakat dalam pengembangan ekowisata Desa Aik Berik. kehadiran LSM mendapat respon negatif dari masyarakat. Pengelaman buruk masyarakat tentang kinerja LSM membuat masyarakat trauma untuk melibatkan LSM dalam pengembangan ekowisata di Desa Aik Berik. Hal tersebut bisa dilihat dari persepsi masyarakat yang menyatakan kurang setuju terhadap keterlibatan LSM sebesar $53.33 \%$. Hal ini terjadi karena kepercayaan masyarakat terhadap LSM sudah menurun, dari pengalaman masyarakat yang pernah ditipu oleh LSM yang berkerjasama dengan Desa Aik Berik. Janji palsu yang diberikan kepada masyarakat sehingga masyarakat menjadi trauma. Kepercayaan bisa dipengaruhi kembali dengan pemberian bukti dan kerja yang nyata dari LSM di Desa Aik Berik.

Persepsi masyarakat terhadap peningkatan keamanan di Desa Aik Berik. Lombok merupakan salah satu dearah yang memiliki kesan (image) negatif mengenai kondisi keamanan. Terjadinya kasus kriminal seperti pencurian, perampokan, penjambretan dan pemerkosaan merupakan bentuk kriminalitas yang sangat mempengaruhi tingkat keamanan wisatawan. Desa Aik Berik yang merupakan salah satu desa di Lombok Tengah menyadari bahwa keamanan masih perlu ditingkatkan dan membutuhkan kerjasama banyak pihak. Masyarakat berpendapat bahwa sangat setuju terhadap peningkatan keamanan sebesar $10 \%$, masyarakat menyatakan setuju sebesar $36.66 \%$, Maka dari hal tersebut dapat dilihat bahwa secara umum keamanan perlu ditingkatkan supaya kegiatan wisata dan aktivitas masyarakat di Desa Aik Berik terjaga dengan baik karena keamanan daya tarik wisata sangat diutamakan oleh wisatawan dalam melakukan perjalanan wisata.

\section{Persepsi Wisatawan terhadap pengembangan ekowisata}

Persespi wisatawan dalam artikel ini terbagi menjadi dua 
yaitu persepsi positif dan negatif yang diuraikan sebagai berikut:

\subsection{Persepsi positif}

Ada beberapa hal yang terkait dengan persepsi positif wisatawan yaitu ekowisata, jalur trekking Gunung Rinjani, pelestarian ekosistem tumbuh-tumbuhan, air terjun sebagai daya tarik ekowisata, agrowisata, perkebunan dan persawahan, sosial budaya masyarakat, pengembangan wisata Cycling, Camping yang diuraikan sebagai berikut :

Persepsi wisatawan terhadap pengembangan ekowisata di Desa Aik Berik. Ekowisata sudah menjadi salah satu daya tarik yang diminati oleh wisatawan saat ini, hal tersebut bisa dibuktikan dengan semakin banyaknya wisatawan yang mengunjungi daya tarik ekowisata tersebut. Wisatawan yang berkunjung ke Desa Aik Berik mendukung pengembangan ekowisata. Hal tersebut terlihat dari pendapat wisatawan yang menyatakan sangat setuju jika dikembangkan ekowisata sebesar 55\%, wisatawan menyatakan setuju sebesar 30\%, ekowisata di Desa Aik Berik memiliki pernanan yang sangat penting terhadap pembangunan desa dan masyarakat lokal. Dukungan wisatawan untuk mengembangkan ekowisata merupakan peluang yang sangat besar untuk menarik wisatawan lebih banyak dan mendatangkan keuntungan bagi masyarakat dan pemerintah.

Perserpsi wisatawan jika Desa Aik Berik dikembangkan sebagai jalur pendakian (trekking) ke Gunung Rinjani. Gunung Rinjani menjadi salah satu gunung tertinggi no 2 di Indonesia. Minat wisatawan melakukan trekking sangat tinggi. Wisatawan Domestik dan Internasional melakukan trekking khususnya di musim banyak pengunjung (high season) dari bulan JuniSeptember. Wisatawan sangat mendukung jika Desa Aik Berik dijadikan sebagai salah satu jalur pendakian (starting point) menuju Gunung Rinjani. Hal tersebut dapat dilihat bahwa wisatawan yang menyatakan sangat setuju terhadap terhadap pengembangan trekking menuju Gunung Rinjani sebesar 10\%, wisatawan menyatakan setuju sebesar $40 \%$, wisatawan yang 
menyatakan netral sebesar $31.66 \%$, wisatawan yang menyatakan tidak setuju sebesar $18.33 \%$. Besarnya dorongan dari wisatawan maka menjadi peluang di Desa Aik Berik dijadikan sebagai jalur pendakian (trekking) menuju Gunung Rinjani.

Persepsi wisatawan tentang pelestarian ekosistem tumbuhtumbuhan di Desa Aik Berik. Ekosistem tumbuhan-tumbuhan di Desa Aik Berik merupakan salah satu daya tarik wisata. Keberadaanya memberikan pengaruh terhadap jumlah debit air yang ada di 3 Air Terjun di Desa Aik Berik. Wisatawan sangat mendukung pelestarian alam. Hal ini ditunjukan bahwa persepsi wisatawan akan dorongan pelestarian itu sangat tinggi. wisatawan yang menyatakan sangat setuju terhadap pelestarian ekosistem tumbuh-tumbuhan sebesar 5\%, wisatawan menyatakan setuju sebesar $58.33 \%$, wisatawan yang menyatakan netral sebesar $20 \%$.

Persepsi wisatawan terhadap pengembangan Air Terjun Benang Stokel, Benang Kelambu \& Kelewon sebagai daya tarik Ekowisata. Daya tarik wisata 3 Air Terjun di Desa Aik Berik memberikan kesan tersendiri yang tidak dimiliki oleh daerah lain di Pulau Lombok. Banyaknya wisatawan yang berkunjung ke Desa Aik Berik merupakan bukti bahwa banyak wisatawan yang tertarik terhadap 3 Air Terjun tersebut. Kehadiran wisatawan di Desa Aik Berik dirasakan sangat penting demi pembangunan ekowisata. Wisatawan menilai bahwa sangat setuju terhadap pengembangan air terjun benang stokel, benang kelambu dan kelewon sebagai daya tarik ekowista sebesar $13.33 \%$, wisatawan menyatakan setuju sebesar $51.66 \%$, wisatawan yang menyatakan netral sebesar $28.33 \%$. Pengembangan Ekowisata di Desa Aik Berik harus memperhatikan 3 Air Terjun sebagai daya tarik wisata.

Persepsi wisatawan terhadap pengembangan Agrowisata di Desa Aik Berik. Pengembangan Agrowisata banyak dikembangkan diberbagai tempat di Indonesia. Karakter lingkungan yang sejuk, memiliki banyak air dan kondisi geografis yang tinggi merupakan wilayah yang bagus untuk dikembangkan agrowisata. Desa Aik Berik juga memiliki peluang dan potensi yang besar dalam pengembangan Agrowisata dan wisatawan juga mendukung 
perkembangan tersebut. Dukungan wisatawan bisa dilihat dari persepsi wisatawan yang menyatakan sangat setuju terhadap pengembangan agrowisata sebesar $8.33 \%$, wisatawan menyatakan setuju sebesar $48.33 \%$, wisatawan yang menyatakan netral sebesar $35 \%$. Maka dari hal tersebut dapat dilihat bahwa agrowisata sangat besar kemungkinanya untuk dikembangkan di Desa Aik Berik.

Persepsi wisatawan terhadap perkembunan dan persawahan untuk dijadikan sebagai daya tarik ekowisata. Desa Aik Berik memiliki kebun dan sawah yang luas dan memiliki pemandangan yang menarik. Banyak wisatawan yang melakukan kegiatan wisata di sekitar sawah dan perkebunan. Wisata trekking merupakan pilihan wisatawan ketika berkunjung ke Desa Aik Berik. Melihat banyaknya wisatawan yang gemar melakukan kegiatan di sekitar sawah dan kebun maka pengembangan daya tarik wisata tersebut sangat didukung oleh wisatawan. Dukungan tersebut dapat dilihat bahwa persepsi wisatawan yang menyatakan sangat setuju terhadap daya tarik perkebunan dan persawahan sebesar $10 \%$, wisatawan menyatakan setuju sebesar $43.33 \%$, wisatawan yang menyatakan netral sebesar $33.33 \%$, wisatawan yang menyatakan tidak setuju sebesar $13.33 \%$. Maka dari hal tersebut dapat dilihat bahwa suasana persawahan dan perkerbunan harus dijaga dengan baik.

Persepsi wisatawan terhadap sosial budaya masyarakat mempengaruhi pariwisata di Desa Aik Berik. Sosial dan Budaya masyarakat merupakan salah satu pendukung berkembangnya daya tarik wisata. Kebudayaan suatu daerah akan mempengaruhi tingkah dan prilaku dalam kehidupan bermasyarakat. Kondisi sosial budaya yang harmonis akan mempengaruhi kehidupan yang bermasyarakat yang harmonis. Wisatawan yang berkunjung ke suatu daerah akan merasa senang dan tenang apabila masyarakatnya harmonis dengan sosial budaya yang baik. Wisatawan merasa senang dan nyaman dengan kondisi sosial budaya masyarakat Desa Aik Berik. hal tersebut bisa dilihat bahwa wisatawan yang menyatakan sangat setuju terhadap pengaruh sosial budaya masyarakat terhadap pariwisata sebesar 
$15 \%$, wisatawan menyatakan setuju sebesar $45 \%$, wisatawan yang menyatakan netral sebesar 30\%. Maka dari hal tersebut dapat dilihat bahwa kebudayaan masyarakat bisa mempengaruhi kegiatan wisatawan selama melakukan kegiatan wisata di Desa Aik Berik.

Persepsi wisatawan terhadap pengembangan wisata sepeda (cycling tour) di Desa Aik Berik. Desa Aik Berik memberikan pesona tersendiri bagi wisatawan yang mengunjungi daya tarik ekowisata. Berbagai jenis atraksi wisata yang bisa dikembangkan untuk melengkapi perkembangan kegiatan ekowisata di Desa Aik Berik. Kegiatan wisata yang bersifat alam dan menantang (adventure) juga bisa dikembangkan. Wisata sepeda (cycling) bisa dikembangkan di Desa Aik Berik. Panorama persawahan dan perkebunan dengan udara yang segar sangat mendukung pengembangan cycling tour. Wisatawan berpadangan sangat baik jika dikembangkan cycling tour. Dari itu, bila dilihat dari persepsi wisatawan yang menyatakan sangat setuju terhadap pengembangan wisata sepeda (cycling tour) sebesar 15\%, wisatawan menyatakan setuju sebesar $50 \%$, wisatawan yang menyatakan netral sebesar $21.66 \%$. Maka dari hal tersebut dapat dilihat bahwa pengembangan wisata sepeda (cycling tour) diminati oleh wisatawan yang berkunjung ke daya tarik wisata di Desa Aik Berik.

Persepsi wisatawan terhadap pengembangan wisata camping di Desa Aik Berik. Berbagai jenis dayar tarik wisata yang bisa dikembangkan di Desa Aik Berik. Pengembangan atraksi yang dikembangkan tentunya terkait dengan daya tarik ekowisata dan ramah lingkungan supaya terjadinya pariwisata yang ramah lingkungan serta berkelanjutan. Atraksi wisata camping merupakan kegiatan yang bisa dikembangkan di Desa Aik Berik. Pengembangan camping didukung oleh wisatawan yang berkunjung di daya tarik wisata Desa Aik Berik. Dukungan tersebut terlihat dengan persepsi wisatawan yang menyatakan sangat setuju terhadap terhadap pengembangan wisata camping sebesar $3.33 \%$, wisatawan menyatakan setuju sebesar $16.66 \%$, wisatawan yang menyatakan netral sebesar $45 \%$. Maka dari hal 
tersebut dapat dilihat bahwa ada peluang untuk dikembangkan wisata camping di Desa Aik Berik.

\subsection{Persepsi negatif}

Adapun persepsi negatif wisatawan terhadap pengembangan ekowisata di Desa Aik Berik yaitu terkait dengan fasilitas umum, pembangunan Hotel $\mathcal{E}$ Restourant, dan aksesibilitas jalan menuju Desa Berik yang diuraikan sebagai berikut :

Persepsi wisatawan tentang penambahan fasilitas umum yang ada di daya tarik wisata yang ada di Desa Aik Berik. Fasilitas umum sangat penting bagi wisatawan yang berkunjung dan melakukan aktivitas di daya tarik ekowisata Desa Aik Berik. Penyedian fasilitas umum merupakan syarat dasar suatu daya tarik ekowisata supaya tidak merusak alam sekitar. Banyaknya sampah di sekitar daya tarik ekowisata juga mengaggu kenyamanan wisatawan, kurangnya tempat sampah dan kesadaran masyarakat merupakan salah satu penyebabnya. Wisatawan sangat mendukung hal tersebut yang dapat dilihat dari persepsi wisatawan yang menyatakan sangat setuju sebesar $60 \%$, wisatawan menyatakan setuju sebesar 35\%, Maka dari hal tersebut dapat dilihat bahwa sangat diperlukan penambahan fasilitas-fasilitas umum khusunya di daya tarik wisata supaya wisatawan merasa nyaman dan puas ketika melakukan kegiatan wisata.

Persepsi wisatawan terhadap pembangunan Hotel \& Restourant di Desa Aik Berik. Kondisi alam dan lokasi Desa Aik Berik saat ini masih belum berkembang dengan baik. Kondisi alam yang masih alami dan belum banyak pembangunan akomodasi memberikan daya tarik. Wisatawan belum begitu setuju dengan pebangunan Hotel \& Restaurant di Desa Aik Berik karena dianggap akan merusak lingkungan. Kemudian, dukungan wisatawan dapat dilihat dengan persepsi wisatawan yang menyatakan sangat setuju terhadap pembangunan Hotel dan Restourant sebesar $6.66 \%$, wisatawan menyatakan setuju sebesar $13.33 \%$, wisatawan yang menyatakan netral sebesar 51.665 , dan wisatawan yang me- 
nyatakan tidak setuju sebesar $21.66 \%$, wisatawan yang menyatakan sangat tidak setuju sebesar $8.33 \%$. Maka dari hal tersebut dapat dilihat bahwa lebih bayak wisatawan yang menyatakan netral dan tidak sutuju pengembangan Hotel $\mathcal{E}$ Restaurant.

Persepsi wisatawan terhadap perbaikan jalan menuju daya tarik wisata di Desa Aik Berik. Aksesibilitas merupakan sarana yang paling penting untuk dikembangkan supaya kegiatan wisatawan dan masyarakat manjadi lancar. Aksesibiltas menuju daya tarik wisata di Desa Aik Berik dianggap perlu dilakukan perbaikan oleh wisatawan. Dari itu dapat dilihat dari pendapat wisatawan yang menyatakan sangat setuju terhadap perbaikan jalan menju daya tarik wisata sebesar $11.66 \%$, wisatawan menyatakan setuju sebesar $45 \%$, wisatawan yang menyatakan netral sebesar $33.33 \%$, wisatawan yang menyatakan tidak setuju sebesar $8.33 \%$, dan wisatawan yang menyatakan sangat tidak setuju sebesar $1.66 \%$. Maka dari hal tersebut dapat dilihat bahwa perbaikan jalan menuju daya tarik ekowisata perlu diperbaiki supaya memperlancar kegiatan wisata.

\section{Simpulan}

Potensi sumber daya alam yang ada di Desa Aik Berik dapat diidentifikasi untuk dijadikan daya tarik ekowisata yaitu panorama persawahan, panorama perkebunan, sungai, air terjun benang stokel, air terjun benang kelambu dan air terjun kelewon. Pembangunan prasarana dan sarana penunjang pariwisata di Desa Aik Berik masih kurang memadai sehingga wisatawan tidak merasa puas terhadap daya tarik wisata yang ada. Atraksi wisata yang bisa dikembangkan terkait dengan ekowisata seperti cycling, rafting, canyoning, camping, trekking, E river tubing untuk membuka lapangan kerja bagi masyarakat lokal. Persepsi masyarakat dan wisatawan terhadap pengembangan ekowisata terdiri dari persepsi positif dan negatif. Persepsi positif ditunjukan terhadap beberapa hal, yaitu pengembangan jalur trekking Gunung Rinjani, pelestarian ekosistem, pemberian pelatihan kepada masyarakat lokal, pengembangan agrowisata, pengembangan 
air terjun benang stokel, benang kelambu dan kelewon sebagai daya tarik ekowisata. Sedangkan persepsi negatif ditunjukan kepada beberapa hal yaitu fasilitas umum yang kurang memadai, pembangunan Hotel \& Restourant, aksesibilitas jalan, keterlibatan lembaga swadaya masyarakat, dan keamanan daya tarik wisata di Desa Aik Berik.

\section{Saran}

Masyarakat Desa Aik Berik harus menjaga kebersihan, menjaga keamanan, menjaga alam dengan baik supaya terciptanya suasana yang nyaman dan aman bagi wisatawan yang berkunjung ke daya tarik ekowisata. Melakukan melakukan penelitian yang lebih spesifik dengan menggunakan prinsif-prinsif dan kriteria ekowisata yang ada ditinggkatan nasional maupun internasional. Melibatkan masyarakat lokal dalam pengembangan ekowisata yang akan memberikan dampak berkelanjutan secara ekonomi dan sosial budaya.

\section{UCAPAN TERIMA KASIH}

Penulis menyampaikan terima kasih kepada Prof. Dr. I Nyoman Darma Putra, M. Litt. selaku Ketua Program Studi Magister Kajian Pariwisata. Rasa terima kasih yang sebesar-besarnya juga disampaikan kepada Prof. Made Sudiana Mahendra, PhD selaku pembimbing I, Dr. I Made Adhika, MSP selaku pembimbing II. Terima kasih yang setulus-tulusnya penulis sampaikan kepada Ibu dan Bapak penulis serta seluruh keluarga yang sudah memberikan dorongan dan motivasi sehingga terselesainya artikel ini. Di samping itu juga, ucapan terima kasih yang setulusnya kepada beberapa teman-teman yang sudah memberikan bantuan dan inspirasi dalam penulisan artikel ini.

\section{PROFIL PENULIS}

Murianto, SST.Par, M.Par adalah Dosen di Akademi Pariwisata Mataram, Nusa Tenggara Barat. Ia menyelesaikan program Diploma III Pariwisata/ Jurusan Usaha Perjalanan Wisata 
pada tahun 2007 di Universitas Mataram. Program Diploma IV Pariwisata di Fakultas Pariwisata tahun 2011, Universitas Udayana. Program Magister Pariwisata tahun 2014, Universitas Udayana. Tahun 2007-2008 pernah berkerja di Manumadi Wisata Kuta Bali. Tahun 2008-2012 pernah berkerja di Hotel Risata Bali Resort \& Spa. Selain sibuk mengurus Travel Agent dan mengajar saat ini, Murianto juga aktif dibeberapa organisasi budaya seperti musik tradisional Lombok, wayang sasak Lombok dan yayasan pengembangan budaya \& pariwisata di Lombok, NTB.

\section{DAFTAR PUSTAKA}

Dalem, A.A.G.R. 2002. Ecotourism in Indonesia (I), Hal 85-97 didalam "Linking Green Productivity to Ecotourism Experience in the Asia-pacific Region" diedit oleh Tor Handloe. Tokyo: Asian Productivity Organization.

Hadi, Agus, Purbathin. 2010. Laporan Hasil Perencanaan Partisifatif Masyarakat di Desa Aik Berik. Nusa Tenggara Barat: Aliansi Lembaga Adidaya Masyarakat.

Irianto. 2011. Dampak Parwisata Terhadap Kehidupan Sosial dan Ekonomi Masyarakat di Gili Trawangan Kecamatan Pemenang Kabupaten Lombok Utara. Jurnal Bisnis \& Kewirausahaan. Vol 7 (3): 188-194.

Jumail, Muhamad. 2012. Pencitraan Kawasan Kuta Lombok Tengah. Jurnal Ilmiah Pariwisata. Denpasar. Ikatan Alumni Kajian Pariwisata Universitas Udayana. Vol. 2 (1): 217-222.

Humaidi. 2013. Laporan pengembangan Desa Aik Berik, Kecamatan Batu Keliang Utara. Lombok Tengah: Kantor Desa Aik Berik.

Kriyantono, Rachmat. 2010. Tehnik Praktis Riset Komunikasi. Jakarta: Prenanda Media Group.

Ramadhan, Ben Fauzi. 2009. Gambaran Persepsi Keselamatan bersepeda motor siswa/i sekolah menengah atas di kota bogor tahun 2009. Jakarta: Universitas Indonesia.

Pitana, I Gde. 2005. Sosiologi Pariwisata. Yogyakarta: Andi.

Sudarto, Gatot. 1990. Ekowisata; Wahana Pelestarian Alam pengembangan ekonomi berkelanjutan dan pemberdayaan Masyarakat. Bandung: Bahana Utama Media. 